\title{
Co-administration of finasteride and the pure anti-oestrogen ICI 182,780 act synergistically in modulating the IGF system in rat prostate
}

\author{
H Huynh, L Alpert ${ }^{1}$, M A Alaoui-Jamali ${ }^{2}, C$ Y Ng \\ and T W M Chan
}

Molecular Endocrinology Laboratory, Division of Cellular and Molecular Research, National Cancer Centre, Singapore 169610
${ }^{1}$ Jewish General Hospital, Department of Pathology, McGill University, Canada
${ }^{2}$ Lady Davis Institute for Medical Research, Department of Medicine, McGill University, Canada
(Requests for offprints should be addressed to H Huynh, Laboratory of Molecular Endocrinology, Division of Cellular and Molecular Research, National Cancer
Centre of Singapore, Singapore 169610; Email: cmrhth@nccs.com.sg)

\begin{abstract}
Prostate cancer is the most diagnosed invasive malignancy in males. Androgens and oestrogens have been implicated in the pathogenesis of prostate cancer. We report herein that the pure anti-oestrogen ICI 182,780 (ICI) reduces $\mathrm{Ki}-67$ labelling index and IGF-I receptor levels in rat prostate. Increase of IGF-I mRNA and IGF-binding protein 3 (IGFBP-3) accumulation occur without any effect on prostate weight. Finasteride significantly decreases prostate weight and inhibits IGF-I gene expression. IGFBP-3 mRNA, Akt and phospho-Akt are not affected by finasteride. Co-administration of ICI plus finasteride reduces prostate weight by approximately $50 \%$ and causes acinar dilation with decreased luminal epithelial
\end{abstract}

cell thickness. The acinar epithelial cells became atrophic and inactive with minimal cytoplasm. We also demonstrate a synergistic effect of ICI and finasteride on induction of IGFBP-3 accumulation and inhibition of Akt phosphorylation. Because the IGF and IGFBP-3 system plays an important role in prostate epithelial cell proliferation, apoptosis and tumour progression, the inhibitory effects of finasteride and ICI on IGF system may contribute to their anti-proliferative activity. These observations support a potential use of ICI in conjunction with finasteride in the prevention and/or treatment of prostate cancer.

Journal of Endocrinology (2001) 171, 109-118

\section{Introduction}

The prostate gland requires androgens for growth, maintenance and function. Androgen-deprivation therapy causes marked and characteristic changes in both normal prostate and prostate cancer (Murphy et al. 1991, Ferguson et al. 1994). The $5 \alpha$-reductase enzyme is responsible for the conversion of testosterone to dihydrotestosterone (DHT) in androgen-dependent target cells (Gormley 1992, Aquilina et al. 1997). DHT has a greater affinity for the androgen receptor (AR) than testosterone, and it plays an important role in the regulation of prostatic growth. Finasteride acts as a competitive and specific inhibitor of $5 \alpha$-reductase, resulting in suppression of serum and intraprostatic DHT concentration to castrated levels, with subsequent reduction in prostatic size (The Finasteride Study Group 1993, Rittmaster 1994, Gormley et al. 1992). Finasteride also inhibits AR expression (Wang et al. 1997). Inhibition of $5 \alpha$-reductase has been shown to inhibit the growth of prostate cancer both in vivo and in vitro (Bologna et al. 1992, Kelloff et al. 1992, Lamb et al. 1992,
Tsukamoto et al. 1995). An attractive feature of finasteride is its excellent safety profile (Gormley et al. 1992, Rittmaster 1994, Stoner 1994, Oesterling 1995, Boyle et al. 1996), making it a reasonable candidate for chemoprevention in high-risk target populations.

Oestrogen receptors are present in fibroblasts, basal epithelial and acinar epithelial cells (Droller 1997). Both oestrogens and DHT decrease the rate of cell death (Droller 1997). Oestrogens induce stromal fibroblasts to express epidermal growth factor receptor (EGF-R) and fibroblast growth factor receptor (FGF-R), increase AR levels and stimulate prostate basal epithelial cells to produce growth factors that act on the epithelial cells (Droller 1997). In dogs, oestrogens cause marked stimulation of prostate growth (Rhodes et al. 2000). Increased serum oestrogens promote prostate growth indirectly by increased growth factor production (Droller 1997).

Several epidemiological studies provided data suggesting that the incidence of prostate cancer is higher in men with higher circulating insulin-like growth factor-I (IGF-I) levels (Chan et al. 1998, Wolk et al. 1998). IGF-I has been 
shown to be an anti-apoptotic agent and acts as a mitogen in the prostate gland. Systemic treatment with IGF-I for 7 days resulted in a $29 \%$ increase in the net weight of the ventral prostate (Torring et al. 1997). Persistent expression of IGF-I in the basal epithelium of mouse prostate leads to neoplasia in this tissue (DiGiovanni et al. 2000). Suppression of IGF-I expression by finasteride was correlated with decrease in prostate weight (Huynh et al. 1998a). Blocking of IGF-II autocrine loop by vitamin D and its analogue EB1089 inhibits PC-3 prostate cancer cell proliferation (Huynh et al. 1998b). The role of IGFs in prostate growth is mediated in part by the interrelated components of the IGF system, which includes IGF receptors, IGF-binding protein (IGFBP) receptors and IGFBP proteases. The IGFBPs are a family of seven proteins that bind to IGFs with high affinity (Jones \& Clemmons 1995, Oh et al. 1996), and control the distribution of IGFs. Normal prostate epithelial cells secrete IGFBP-2 and IGFBP-4, whereas the stromal fibroblasts produce IGFBP-2, 3 and 4 (Cohen et al. 1991, 1994a). Following castration, the expression of IGFBP-2, 3, 4 and 5 genes in the ventral prostate is rapidly induced (Nickerson et al. 1998). It has been hypothesized that IGFBPs attenuate the cellular response to IGF-I through the high affinity binding of IGF-I to IGFBPs. This interaction sequesters IGF-I away from its receptor, and hence interfering with the normal homeostatic intracellular signalling downstream of the receptor. It is also known that some IGFBPs have intrinsic bioactivity, which is independent of IGF (Oh et al. 1993, Huynh et al. 1996, Rajah et al. 1997). IGFBP-3 can have an inhibitory activity, probably through transforming growth factor- $\beta$ (TGF- $\beta$ ) receptor type V (Leal et al. 1997). Changes in IGFBP-3 levels from benign to malignant disease has been reported (Thrasher et al. 1996). In the process of neoplastic progression, activation of autocrine loops is a common event. Neoplastic progression is associated with the expression of IGFBP proteases. In the tumour microenvironment, these would tend to increase IGF bioactivity by cleaving IGFBPs and liberating free IGFs. In humans, prostate-specific antigen (PSA) is a proteolytic enzyme that cleaves IGFBP-3 in extracellular fluid (Peehl et al. 1996), and an inverse correlation between PSA and IGFBP-3 levels in bone metastases has been reported (Smith et al. 1999). Epidemiological observations linking IGF-I to risk of prostate cancer provided potential implications of the IGF system as a target for prevention (Chan et al. 1998, Wolk et al. 1998).

In this study, we report that blockage of oestrogen action by a pure anti-oestrogen ICI 182,780 (ICI) (Wakeling et al. 1991) and reduction of DHT levels by finasteride lead to reduction of IGF-mediated autocrine/ paracrine loops and reduction in prostate weight. This approach may offer a clinical utility for prostate cancer and/or benign prostatic hyperplasia.

\section{Materials and Methods}

\section{Animals}

Animal studies were performed in agreement with the guidelines of the local Animal Care. To block the conversion of testosterone to DHT, male Sprague-Dawley rats $(n=15)$ (Charles River, Quebec, Canada) weighing 300$350 \mathrm{~g}$ were treated with $5 \mathrm{mg}$ finasteride/ $\mathrm{kg}$ body weight/ day (5 mg/tablet, Merck Frost, Quebec, Canada) by gavage. The finasteride dose was based on our previous studies (Huynh et al. 1998a). Control animals $(n=15)$ received the same volume of vehicles. To block oestrogen activity, ICI (Wakeling et al. 1991) (AstraZeneca Pharmaceuticals, Macclesfield, Cheshire, UK) was supplied at a concentration of $50 \mathrm{mg} / \mathrm{ml}$ in castor oil solution. Rats received castor oil $(n=15)$ or either $1 \mathrm{mg}(n=15)$ or $1.5 \mathrm{mg}(n=15)$ ICI per $\mathrm{kg}$ body weight per week for 3 consecutive weeks. To investigate the combined effects of ICI and finasteride, rats (15 rats per group) were daily treated with $5 \mathrm{mg}$ finasteride $/ \mathrm{kg}$ body weight plus either $1 \mathrm{mg}$ ICI or $1.5 \mathrm{mg}$ ICI per $\mathrm{kg}$ body weight per week for 3 consecutive weeks. Animals were sacrificed 21 days following the initial treatment and the prostate tissue was collected and weighed. A portion of the prostate tissue was fixed in $10 \%$ buffered formalin for paraffin embedding and the remainder was immediately frozen in liquid nitrogen for extraction of RNA and protein.

\section{Immunohistochemistry and histology}

Fixed prostate tissue was routinely processed in a tissue processor and embedded in paraffin. Sections of $5 \mu \mathrm{m}$ were cut and stained with haematoxylin-eosin. Examination of the slides was performed by light microscopy. The ImmunoCruz Staining System was used for immunohistochemical study. Briefly, the slides were deparaffinized and rehydrated gradually through graded alcohols: washed in $100 \%$ ethanol twice for $10 \mathrm{~min}$ each, 95\% ethanol twice for $10 \mathrm{~min}$ each, and $75 \%$ ethanol twice $5 \mathrm{~min}$ each. The slides were washed in deionized water for another $3 \mathrm{~min}$ and incubated with $3 \% \mathrm{H}_{2} \mathrm{O}_{2}$ for 20 min to block endogenous peroxidase activity. To examine expression of $\mathrm{Ki}-67$, antigens were retrieved by heating the slides in citrate buffer $(\mathrm{pH} 6.0)$ at $95{ }^{\circ} \mathrm{C}$ for $5 \mathrm{~min}$. After preincubation with normal serum for $20 \mathrm{~min}$ at room temperature, the primary antibody was applied $(2 \mu \mathrm{g} / \mathrm{ml})$ and incubated overnight at $4{ }^{\circ} \mathrm{C}$. The section was then incubated with the appropriate biotinylated secondary antibody at 1:500 dilution followed by peroxidase-conjugated streptavidin complex, according to the manufacturer's instruction, and diaminobenzidene. The section was then counterstained with haematoxylin. Between each change of incubation the sections were rinsed three times in PBS for 5 min each. To evaluate the Ki-67 labelling index, 500 epithelial cells were counted for each group in randomly chosen fields at a magnification of 400 . The Ki-67 
labelling index was expressed as the number of clearly labelled Ki-67 reactive nuclei in 500 cells counted. Significance difference was determined by Student's $t$-test.

\section{Western blotting}

To determine the changes in the expression of IGFIR, IGFBP-3, Akt, phosphatidylinositol-3-kinase (PI-3 kinase) $\mathrm{p} 85$ and phospho mitogen-activated protein kinase (MAPK) ( $\left.\mathrm{Thr}^{202} / \mathrm{Tyr}^{204}\right)$, prostate tissue was homogenized in lysis buffer $\left(1 \mathrm{mM} \mathrm{CaCl}, 1 \mathrm{mM} \mathrm{MgCl}_{2}, 1 \%\right.$ $\mathrm{NP}-40,1 \mu \mathrm{g} / \mathrm{ml}$ leupeptin, $1 \mu \mathrm{g} / \mathrm{ml}$ aprotinin, $1 \mu \mathrm{M}$ PMSF, and $100 \mu \mathrm{M} \mathrm{NaVO}$ ). Proteins were subjected to Western blot analysis as described (Huynh et al. 1995). Blots were incubated with either rabbit anti-IGF-IR $\beta$ $(1 \mu \mathrm{g} / \mathrm{ml})$ (Santa-Cruz Biotechnology Inc., Santa Cruz, CA, USA), rabbit anti-IGFBP-3 (1:500) (Upstate Biotechnology, Lake Placid, NY, USA), mouse anti-phospho specific MAPK $\left(\mathrm{Thr}^{202} / \mathrm{Tyr}^{204}\right)(1 \mu \mathrm{g} / \mathrm{ml})$ (New England BioLabs, Beverly, MA, USA), rabbit anti-phospho-Akt $\left(\mathrm{Ser}^{473}\right)$ (New England BioLabs) and mouse anti- $\alpha$ tubulin $(0.5 \mu \mathrm{g} / \mathrm{ml}) \quad$ (Santa-Cruz) antibodies and horseradish peroxidase-conjugated donkey anti-mouse or anti-rabbit secondary antibody (1:7500). Blots were visualized with a chemiluminescent detection system as described by the manufacturer (ECL, Amersham). Quantitative analysis of protein expression was accomplished by scanning autoradiograms and densitometry.

\section{Northern blot}

Total RNA was isolated from prostate tissue and Northern blotting was performed as described (Huynh et al. 1993). Blots were hybridized with IGF-I (Murphy et al. 1987), IGF-IR (ATCC), and IGFBP (1-5) (Shimasaki \& Ling 1991) cDNAs. To control for equal RNA loading, blots were rehybridized with glyceraldehyde-3-phosphate dehydrogenase (GAPDH) cDNA (ATCC). Quantitative analysis of gene expression was accomplished by scanning autoradiograms and densitometry. For each lane, the sum of the density of bands corresponding to transcripts hybridizing with the probe under study was calculated, and normalized the amount of RNA loaded.

\section{Statistical analysis}

Differences in prostate weight, Ki-67 labelling index, gene expression and the levels of proteins under study were analysed by the Mann-Whitney $U$ test. $P<0.01$ was considered significant.

\section{Results}

\section{Effects of ICI and finasteride on the prostate weight}

Treatment of rats with a pure anti-oestrogen, ICI, for 3 weeks had no effect on prostate weight. Daily treatment of finasteride at a dose of $5 \mathrm{mg} / \mathrm{kg}$ body weight caused a $25 \%$ reduction in prostate weight $(P<0 \cdot 01)$ (Fig. 1). Prostate weight was about $50 \%$ of controls when ICIwas coadministered with finasteride $(P<0 \cdot 01)$ (Fig. 1). When co-administration with $5 \mathrm{mg}$ of finasteride, the dose of ICI required to yield a maximal reduction in prostate weight was $1 \mathrm{mg}$ per $\mathrm{kg}$ body weight.

\section{Effects of ICI and finasteride on the prostate morphology}

The effects of ICI, finasteride and the combination on prostate gland morphology are shown in Fig. 2. Control prostate gland presents a cluster of epithelial tubules surrounded by connective tissue. The epithelial ducts had a large lumen, lined by tall cubical cells. The luminal cells were large and apparently active. Most of the nuclei in the finasteride-treated gland were arranged in a basal manner, with some nuclei arranged in an irregular fashion (Fig. 2B). There were no apparent differences in the luminal cell morphology between vehicle and finasteride-treated prostate glands (Fig. 2A vs 2B). Co-administration of ICI and finasteride resulted in marked histological changes of the prostate gland (Fig. 2D). The ICI/finasteride-induced pattern was characterized by an increased size of the lumen (data not shown). The epithelial layer lining the lumen was very thin. The epithelial cells were inactive, with diminished cytoplasm (Fig. 2D).

Effects of ICI and finasteride on the prostate epithelial cell proliferation

We examined the effect of hormonal regulation of Ki-67 expression in prostate tissue. Figure 3 shows the results of an experiment where prostate tissues were collected from rats treated with vehicle, finasteride, ICI, and ICI plus finasteride. Both finasteride and ICI caused an insignificant decrease in the number of epithelial cells expressing $\mathrm{Ki}-67$ as compared with controls $(P<0 \cdot 01)$. No significant reduction in the Ki-67 labelling index of the epithelium was seen when ICI and finasteride were co-administered as compared with the effect of either ICI or finasteride alone. A significant decrease in Ki-67 index was observed as compared with control gland when the two drugs were co-administered $(P<0 \cdot 01)$.

\section{Effects of ICI and finasteride on the IGF system}

Since over-expression of IGF-I in the basal epithelium of prostate leads to spontaneous hyperplasia (DiGiovanni et al. 2000) and systemic injection of IGF-I increased wet weight of the ventral prostate (Torring et al. 1997), the in vivo effects of ICI, finasteride and finasteride plus ICI on IGF-I, IGF-I receptor and IGFBP expression were examined. As shown in Fig. 4, daily treatment of male rats with $5 \mathrm{mg}$ finasteride per $\mathrm{kg}$ body weight resulted in $30 \%$ decrease in IGF-I mRNA $(P<0 \cdot 05)$. ICI, at a dose of 


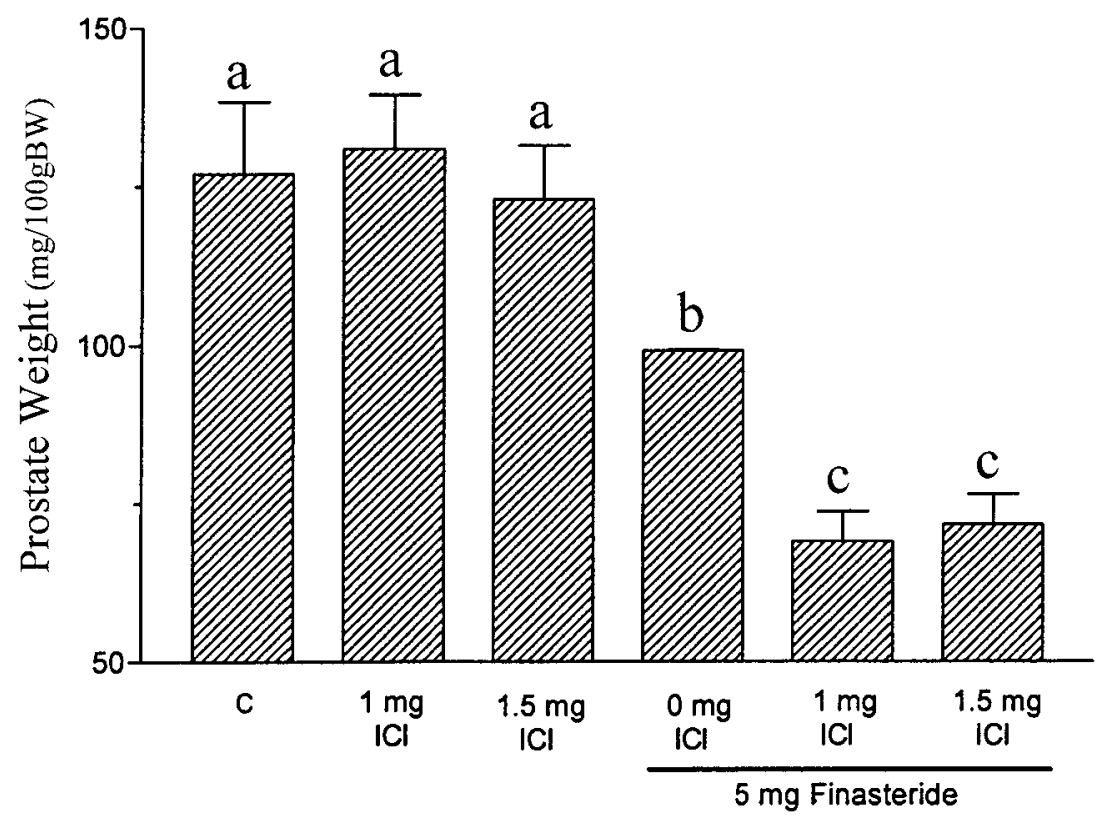

Figure 1 Effects of $\mathrm{ICl}$, finasteride and $\mathrm{ICl}$ plus finasteride on rat prostate weight. Rats were treated with the indicated concentrations of finasteride $(n=15), \mathrm{ICl}(n=15)$ and $\mathrm{ICI}$ plus finasteride $(n=15)$ for 3 weeks. C represents control rats treated with vehicle $(n=15)$. Prostate tissues were collected, weighed individually and plotted. Bars with different letters are significantly different from one another at $P<0.01$ as determined by the Mann-Whitney $U$ test. Data are expressed as the mean of 15 samples \pm S.E.M.

$1.5 \mathrm{mg}$, caused a $1 \cdot 8$-fold increase in IGF-I transcripts as compared with controls $(P<0 \cdot 01)$. The IGF-I gene expression was significantly inhibited when finasteride and ICI were co-administered $(P<0 \cdot 01)$. Neither ICI nor finasteride had significant effects on IGFBP-3 mRNA when administered as a single agent $(P<0 \cdot 01)$. However, when they were given together, the IGFBP-3 mRNA levels were significantly augmented $(P<0 \cdot 01)$ (Fig. 4B).

The IGF-I receptor protein was significantly decreased by ICI $(P<0 \cdot 01)$. One mg of ICI per kg body weight was sufficient to inhibit IGF-IR expression (Fig. 5). Finasteride increased IGF-IR levels non-significantly $(P<0 \cdot 01)$. When ICI was co-administered with finasteride, significant inhibition of IGF-IR expression was observed only at $1.5 \mathrm{mg}$ ICI $(P<0 \cdot 01)$ (Fig. 5). Despite significant reduction in IGF-IR following ICI or combined ICI and finasteride, the levels of MAPK phosphorylation were not significantly affected $(P<0 \cdot 01)$ (Fig. 5$)$.

Since IGF-I is mitogen for prostate cancer cells and IGFBP-3 modulates activity of IGF-I (Clemmons 1997), the effects of ICI, finasteride and finasteride plus ICI on IGFBP-3 levels were examined. Figure 6 shows that IGFBP-3 levels were significantly increased by either ICI or finasteride $(P<0 \cdot 01)$. ICI-induced IGFBP-3 synthesis was dose-dependent. Further significant increase in IGFBP-3 accumulation was observed in ICI plus finasteride treated prostate tissues $(P<0 \cdot 01)$.
Since PI-3 kinase activity is very important for IGF-Iinduced mitogenesis and anti-apoptosis (Yenush \& White 1997, White \& Yenush 1998), the levels of PI-3 kinase p85 and its downstream target Akt were investigated. Figure 7 shows that levels of PI-3 kinase p 85 and Akt did not change as a result of ICI + finasteride treatments. However, the basal phosphorylation of Akt was significantly reduced by ICI + finasteride treatment $(P<0 \cdot 01)$.

\section{Discussion}

Both oestrogens and androgens are essential for prostate growth. Androgen deprivation therapy is widely used for advanced disease and significant advances have come with luteinizing hormone-releasing hormone (LHRH) analogues and anti-androgens. We report herein that in vivo interruption of oestrogen action using a pure anti-oestrogen ICI for 3 weeks had no effect on prostate weight while blockade of the conversion of testosterone to DHT by finasteride reduced prostate weight by approximate $25 \%$. The ability of finasteride to reduce prostate weight was enhanced by combined treatment.

Histological studies revealed that either finasteride or ICI when administered independently exerted insignificant reductions of the thickness of prostate luminal epithelial cells as compared with controls. The luminal 
A
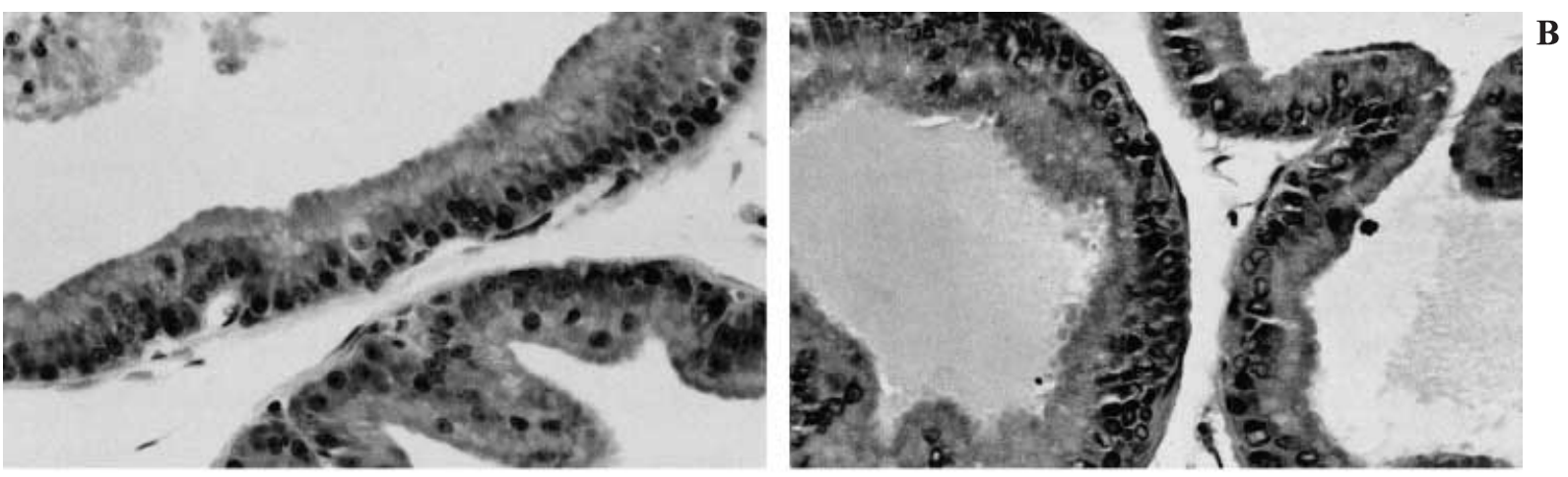

C
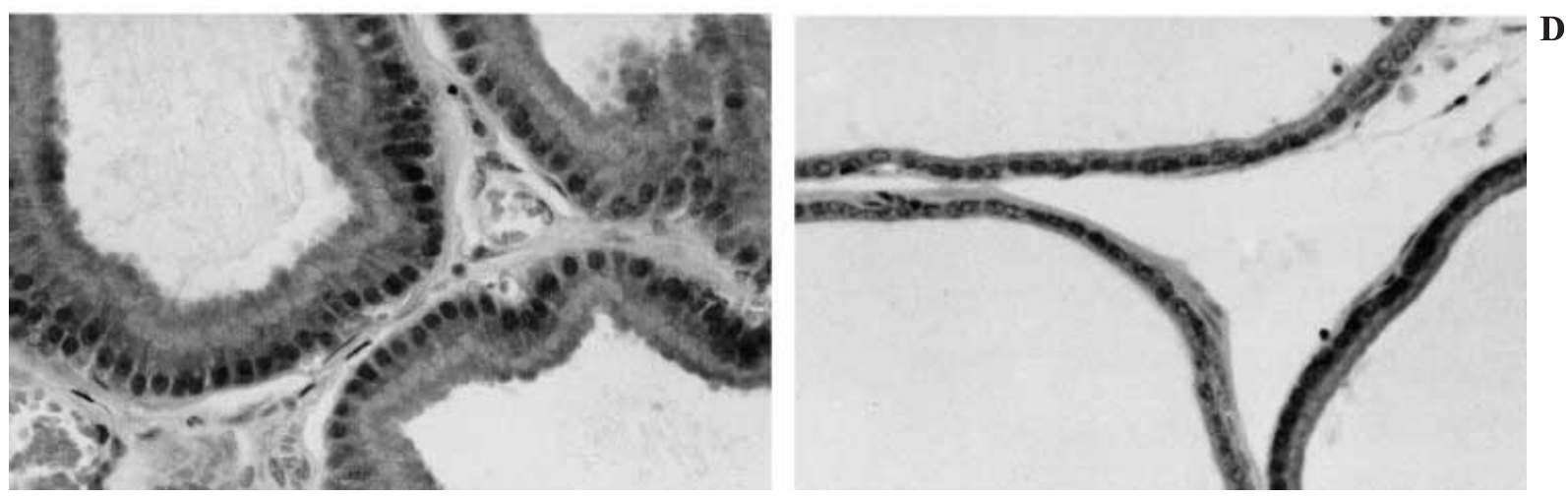

Figure 2 Prostate gland morphology in rats treated with vehicle (A), ICl $1.5 \mathrm{mg} / \mathrm{kg}$ body weight/week (B), finasteride (daily $5 \mathrm{mg} / \mathrm{kg}$ body weight) (C), or finasteride plus ICI (D). Note the basal nuclei seen in ICl-treated gland (B). Finasteride plus $\mathrm{ICl}$ caused acinar dilation. Luminal epithelial cells were atrophic and lost secretory activity. Haematoxylin-eosin stain was used; magnification $\times 1050$.

epithelial cells in ICI-treated gland became columnar and a single layer of regular basal nuclei was seen. This pattern is typical of terminally differentiated epithelial cells. The dilated glandular and luminal epithelial cell atrophy were observed when ICI and finasteride were given together. Although significant reduction in prostate weight following ICI+ finasteride treatment was observed, DNA content per mg of prostate tissue was not significantly different among all treatments (data not shown), suggesting that the observed changes in prostate was mainly due to the decrease in cell volume.

In the present study we observed that both finasteride and anti-oestrogen ICI caused similar reduction in Ki-67 index. However, only finasteride significantly reduced prostate weight but not ICI. This observation could be due to a single point measurement ( 3 weeks post-treatment). It is possible that ICI as a single agent may require a longer period of time to exert significant effects on prostate weight. In addition to the changes in proliferation, the reduction in luminal epithelial cell volume observed in finasteride/ICI treatment is more likely responsible for the decrease in prostate weight.

Oestrogen receptors (ER- $\alpha$ and ER- $\beta$ ) are present in human and rat prostate (Beurden-Lamers et al. 1974, Jung-Testas et al. 1981). Localization of ER- $\beta$ mRNA in prostate epithelial cells, as opposed to stromal localization for ER- $\alpha$ (Prins et al. 1998), indicates that ER- $\beta$ may activate a different set of genes than ER- $\alpha$ in response to oestrogenic stimulation. It is not known whether an ER- $\alpha$ or an ER- $\beta$-mediated pathway is involved in accounting for the observed effects of ICI on prostate weight seen in this present study. Although the role of the ER in the prostate is not well understood, it is a member of a superfamily of transcription factors that regulate gene expression in a variety of cells. Oestrogens are, besides androgens, implicated in the growth of the prostate (Griffiths et al. 1991), and consequently oestrogens have been implicated in the pathogenesis of benign prostatic hyperplasia (Habenicht et al. 1993). There is firm evidence that many biological processes of prostate epithelial tissue are controlled by androgens and oestrogens through the production of stimulatory or inhibitory factors by the stroma and the adjacent epithelial tissue (Cunha et al. 1987, Prins \& Birch 1995). The observation that antioestrogen ICI can decrease Ki-67 labelling index suggests that in vivo oestrogens may induce prostate epithelial cell proliferation in an autocrine, intracrine or paracrine fashion.

Anti-oestrogens such as ICI compete with oestrogens for oestrogen receptors and evoke a different receptor 


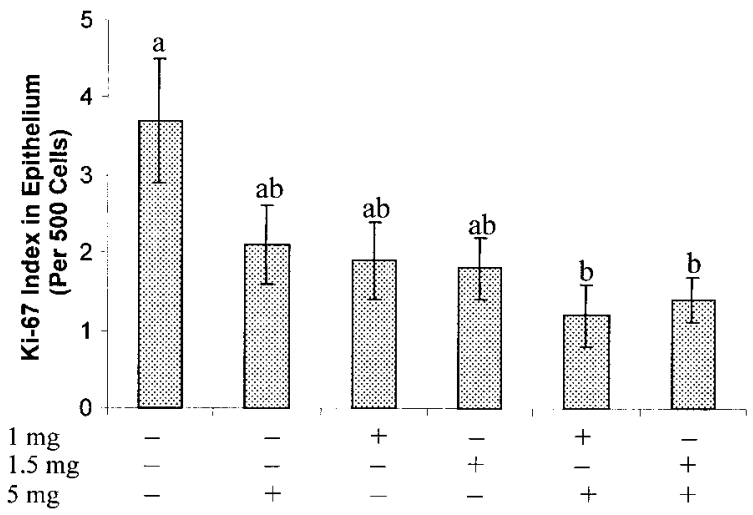

Figure 3 Effects of treatment with $\mathrm{ICl}$, finasteride or $\mathrm{ICl}$ plus finasteride on proliferation of prostate epithelial cells. Rats were treated with the indicated dose of $\mathrm{ICl}$, finasteride and finasteride plus $\mathrm{ICl}$ as described in Materials and Methods. Ki-67 labelling index of epithelial cells was determined as described in Materials and Methods. Bars with different letters are significantly different from one another at $P<0 \cdot 01$ as determined by the Mann-Whitney $U$ test. Data are expressed as the mean of eight samples \pm S.E.M.

conformation that results in reduced or no production of oestrogen-dependent genes such as EGF, EGF-R and FGF-R (Droller 1997). Thus, blocking of oestrogen activity can also disrupt paracrine production of growth factors that act on the epithelial cells. The loss of autocrine stimulatory activity on the stromal cells or paracrine activity on the epithelium by co-administration of ICI plus finasteride may inhibit epithelial cell activity as indicated by the decrease in cytoplasmic volume of luminal epithelial cells, with subsequent reduction in the size of the prostate. Since IGF-I has been reported to be required for an increase in the size of prostate epithelial component (Torring et al. 1997), the reduction in IGF-I and upregulation of IGFBP-3 levels by combined treatments would lead to reduction in the size of luminal epithelial cells. These observations suggest that the growth-promoting effects of oestrogens and androgens in vivo may be mediated, at least in part, by a local synthesis of growth factors such as IGF-I and IGFBP-3, based on the hypothesis that the structure and function of the epithelium of the adult prostatic gland is dependent on epithelial-stromal interactions (Cunha 1994).

Both prostate cancer and benign prostate stromal cells have IGF-I receptors, and stromal cells produce IGF-I in response to androgen (Cohen et al. 1994b). IGF-I could act via an autocrine stimulatory activity on the stroma cells, or paracrine activity on the epithelium. Inhibition of IGF-IR expression may lead to reduction in IGF-I stimulation, which in turn reduces epithelial cell proliferation. IGF-IR has also been shown to play an important role in apoptosis, metastasis of prostate cancer cells (Burfeind et al. 1996) and tumorigenesis (DiGiovanni et al. 2000); inhibition of IGF-IR by ICI and ICI plus finasteride observed in this

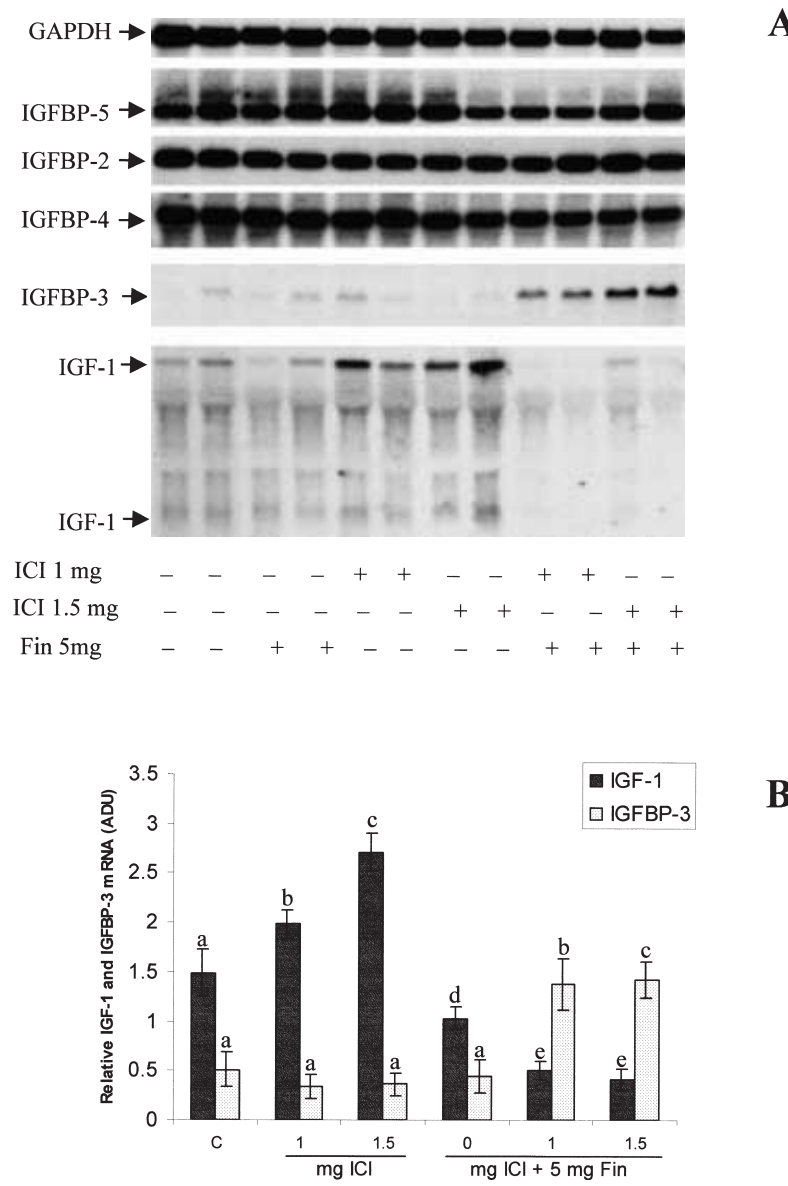

Figure 4 Effects of $\mathrm{ICl}$, finasteride and finasteride plus $\mathrm{ICl}$ on the expression of IGF-I and IGFBPs in the prostate gland. Rats were treated with the indicated dose of $\mathrm{ICl}$, finasteride and finasteride plus $\mathrm{ICl}$ as described in Materials and Methods. Total RNA derived from prostate gland was subjected to Northern blot analysis. Blots were hybridized with IGF-I, IGFBPs (2-5) and GAPDH cDNAs (A). Densitometric scanning of the IGF-I and IGFBP-3 bands is shown in (B). Data are expressed as the mean of eight samples \pm S.E.M. Bars with different letters are significantly different from one another at $P<0 \cdot 01$ as determined by the Mann-Whitney $U$ test. Representative samples are shown. ADU, arbitrary densitometric units.

study is important because such treatments may suppress tumour growth and reduce or abolish tumour invasion (Burfeind et al. 1996). Inhibition of IGF-IR also disrupts the IGF-II autocrine loop, which is quite common in prostate cancer. It remains to be established whether a decrease in IGF-IR and IGF-I expression does occur in prostate tumours following $\mathrm{ICI} /$ finasteride treatment.

Our data suggest that in the prostate, IGF-IR expression is oestrogen-dependent while IGF-I expression is androgen-dependent. Induction of IGF-I gene expression following ICI treatment may provide, in part, an explanation for the failure of ICI to decrease prostate weight. Increase in levels of testosterone and decreased DHT 


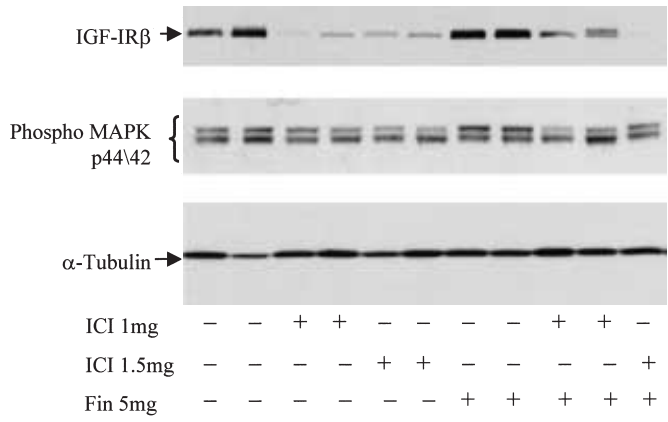

$\mathbf{A}$

B

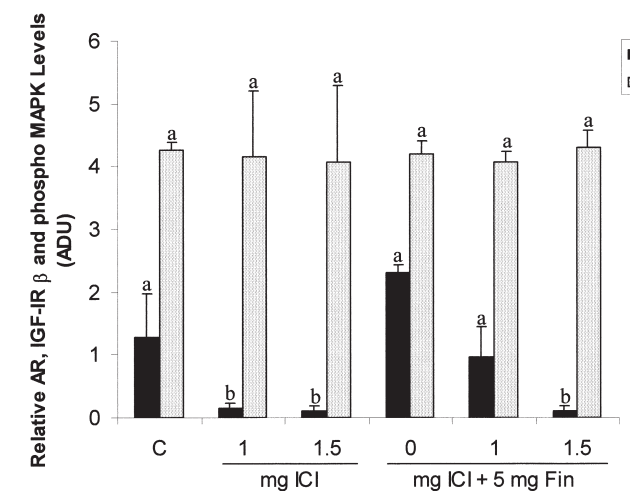

Figure 5 Effects of $\mathrm{ICl}$, finasteride and $\mathrm{ICl}$ plus finasteride on IGF-I receptor and MAPK phosphorylation levels. Rats were treated with the indicated dose of $\mathrm{ICl}$, finasteride and finasteride plus $\mathrm{ICl}$ as described in Materials and Methods. Proteins extracted from prostate glands were analysed by Western blot analysis as described in Materials and Methods. Blots were incubated with rabbit anti-IGF-I receptor $\beta$ (IGF-IR $\beta$ ), mouse anti-phospho MAPK $\left(\mathrm{Thr}^{202} / \mathrm{Tyr}^{204}\right.$ ) (Phospho MAPK p44/42) and anti-mouse $\alpha$-tubulin $(\alpha$-Tubulin) antibodies and horseradish peroxidase conjugated secondary antibodies as described in Materials and Methods (A). Blots were visualized with a chemiluminescent detection system. Densitometric scanning of the IGF-IR $\beta$ and phospho MAPK bands is shown in (B). Data are expressed as the mean of eight samples \pm S.E.M. Bars with different letters are significantly different from one another at $P<0 \cdot 01$ as determined by the Mann-Whitney $U$ test. Representative samples are shown. ADU, arbitrary densitometric units.

following finasteride treatment has been reported (Huynh et al. 1998a). Thus, a slight decrease in prostate weight following finasteride administration may be due to conversion of testosterone to oestrogens, which in turn maintain AR and androgen activity.

The observation that ICI when co-administered with finasteride upregulates IGFBP-3 accumulation is significant given the mitogenic activity of IGF-I and antiproliferative activity of IGFBP-3. The changes in IGF-I and IGFBP-3 following anti-oestrogen-androgen-based therapies was reported here to be similar to castration (Nickerson et al. 1998) and vitamin D analogue-induced apoptosis in rat prostate gland (Nickerson \& Huynh 1999). Increase in IGFBP-3 would prevent the interaction of

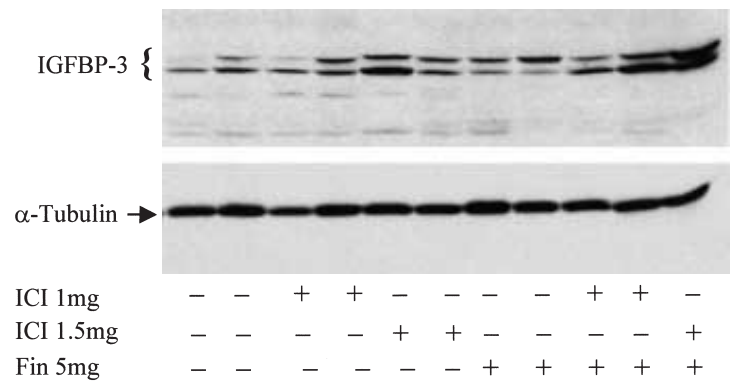

A

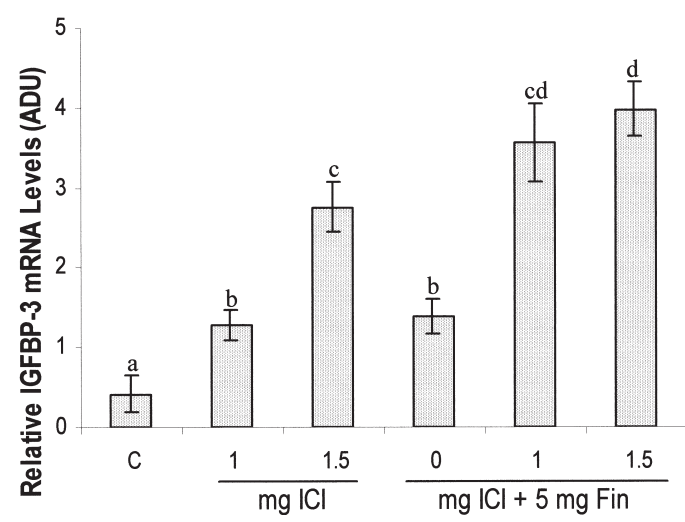

Figure 6 Effects of $\mathrm{ICl}$, finasteride and $\mathrm{ICl}$ plus finasteride on IGFBP-3. Rats were treated with the indicated dose of $\mathrm{ICI}$, finasteride and finasteride plus $\mathrm{ICl}$ as described in Materials and Methods. Proteins extracted from prostate glands were analysed by Western blot analysis as described in Materials and Methods. Blots were incubated with rabbit anti-IGFBP-3 (IGFBP-3), and anti-mouse $\alpha$-tubulin ( $\alpha$-Tubulin) antibodies and horseradish peroxidase conjugated secondary antibodies (A). Blots were visualized with a chemiluminescent detection system.

Densitometric scanning of the IGFBP-3 bands is shown in (B). Data are expressed as the mean of eight samples \pm S.E.M. Bars with different letters are significantly different from one another at $P<0.01$ as determined by the Mann-Whitney $U$ test.

Representative samples are shown. ADU, arbitrary densitometric units.

IGF-I with its receptor and decrease mitogenic activity. Furthermore, IGFBP-3 may inhibit prostate epithelial cells through TGF- $\beta$ receptor type V (Leal et al. 1997). At the present time, it is not known whether upregulation of IGFBP-3 by the combination also induced apoptosis in luminal epithelial cells. Experiments are under way to determine this possibility.

It has been reported that IGF-I can rescue cancer cells from doxorubicin-induced apoptosis and the process requires PI-3 kinase (Gooch et al. 1999). Recent work into IGF-I anti-apoptosis signalling has demonstrated the importance of PI-3 kinase and its downstream substrate Akt (Kulik et al. 1997, Franke et al. 1995). Furthermore, a 


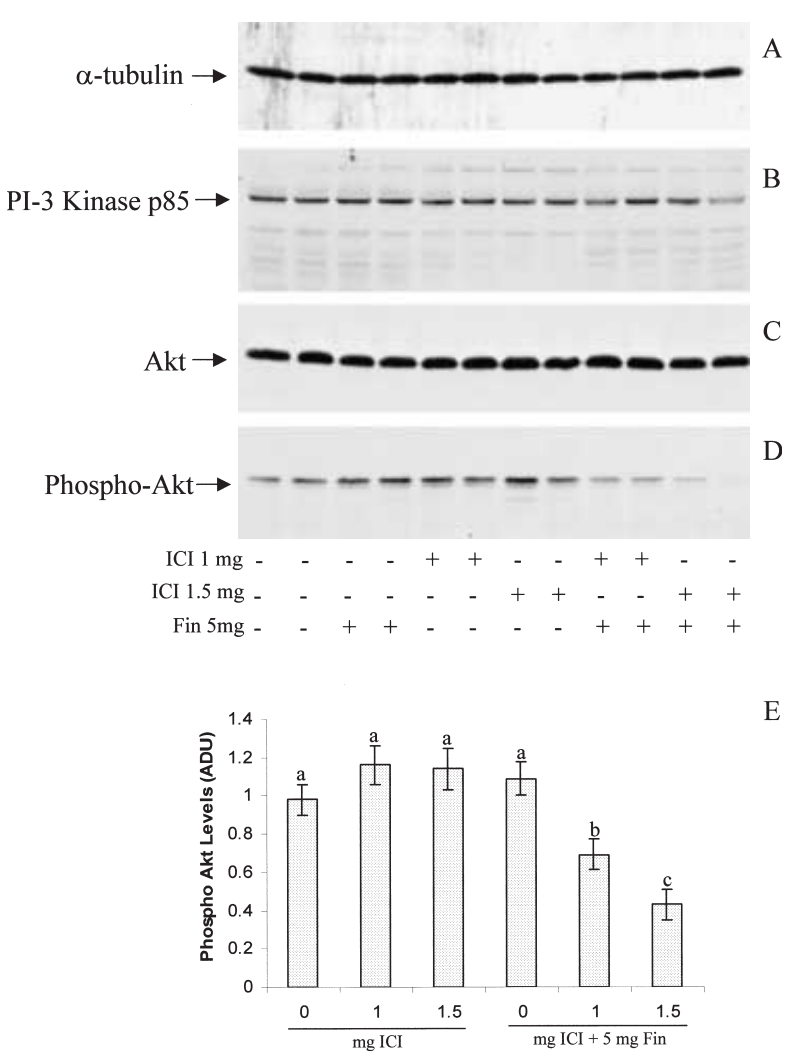

Figure 7 Effects of $\mathrm{ICl}$, finasteride and finasteride plus $\mathrm{ICl}$ on $\mathrm{PI}-3$ kinase p85, Akt and phospho-Akt in rat prostate gland. Rats were treated with the indicated dose of $\mathrm{ICl}$, finasteride and finasteride plus $\mathrm{ICl}$ as described in Materials and Methods. Proteins extracted from prostate glands were analysed by Western blot analysis as described in Materials and Methods. Blots were incubated with anti- $\alpha$-tubulin (A) and anti-PI-3 kinase p85 (B), anti-Akt (C) and phospho-Akt $\left(\mathrm{Ser}^{473}\right)$ (D) antibodies. Densitometric scanning of the IGFBP-3 bands is shown in (E). Data are expressed as the mean of eight samples \pm S.E.M. Bars with different letters are significantly different from one another at $P<0 \cdot 01$ as determined by the Mann-Whitney $U$ test. ADU, arbitrary densitometric units.

direct link between PI-3 kinase and the apoptosisregulating protein $\mathrm{Bcl}$ family of proteins has been established through Akt phosphorylation of BAD (Datta et al. 1997, Zha et al. 1996). Thus the ability of finasteride/ ICI combination to reduce Akt phosphorylation may be important for finasteride/ICI-induced apoptosis. Experiments are under way to determine whether ICI+ finasteride combination also induces prostate epithelial cell apoptosis in vivo.

Combined treatments have been shown to improve survival (Labrie et al. 1983) and disease-free survival (Crawford et al. 1989) in prostate cancer patients as compared with monotherapy. Several other studies have confirmed the benefit of adding early adrenal androgen blockage to medical or surgical castration (Crawford 1990, Denis et al. 1993, Janknegt et al. 1993). Other studies have failed to show survival advantages at early analysis
(Lunglmayr 1990, Beland et al. 1991). Our present study shows that ICI acts synergistically with finasteride to reduce prostate weight and IGF bioavailability. These observations may provide insight into fundamental mechanisms by which oestrogens influence normal prostate growth, androgen-independent growth and metastasis of prostate cancer cells. They provide a novel combined therapy for benign prostatic hyperplasia and prostate cancer.

\section{Acknowledgements}

We would like to thank Drs A. Wakeling and B. Vose (AstraZeneca Pharmaceuticals) for pre-formulated ICI, Dr Jacques Courville (Merck Frost) for Prosca, and Dr R.J. Epstein for a critical reading and helpful discussion of the manuscript. This work was supported in part by grants from the BMRC-NSTB and Medical Research Council of Singapore to Hung Huynh.

\section{References}

Aquilina JW, Lipsky JJ \& Bostwick DG 1997 Androgen deprivation as a strategy for prostate cancer chemoprevention. Journal of the National Cancer Institute 89 689-696.

Beland G, Elhilali M, Fradet Y, Laroche B, Ramsey EW, Trachtenberg J, Venner PM \& Tewari HD 1991 Total androgen ablation: Canadian experience. Urologic Clinics of North America 18 75-82.

Beurden-Lamers WM, Brinkmann AO, Mulder E \& van der Molen HJ 1974 High-affinity binding of oestradiol-17 beta by cytosols from testis interstitial tissue, pituitary, adrenal, liver and accessory sex glands of the male rat. Biochemistry Journal 140 495-502.

Bologna M, Muzi P, Biordi L, Festuccia C \& Vicentini C 1992 Antiandrogens and 5-alpha reductase inhibition of the proliferation rate in PC3 and DU145 human prostatic cancer cell lines. Current Therapeutic Research 51 799-813.

Boyle P, Gould AL \& Roehrborn CG 1996 Prostate volume predicts outcome of treatment of benign prostatic hyperplasia with finasteride: meta-analysis of randomized clinical trials. Urology 48 398-405.

Burfeind P, Chernicky CL, Rininsland F, Ilan J \& Ilan J 1996 Antisense RNA to the type I insulin-like growth factor receptor suppresses tumor growth and prevents invasion by rat prostate cancer cells in vivo. PNAS 93 7263-7268.

Chan JM, Stampfer MJ, Giovannucci E, Gann PH, Ma J, Wilkinson P, Hennekens CH \& Pollak M 1998 Plasma insulin-like growth factor-I and prostate cancer risk: a prospective study. Science $\mathbf{2 7 9}$ 563-566.

Clemmons DR 1997 Insulin-like growth factor binding proteins and their role in controlling IGF actions. Cytokine and Growth Factor Reviews 8 45-62.

Cohen P, Peehl DM, Lamson G \& Rosenfeld RG 1991 Insulin-like growth factors (IGFs), IGF receptors, and IGF-binding proteins in primary cultures of prostate epithelial cells. Journal of Clinical Endocrinology and Metabolism 73 401-407.

Cohen P, Peehl DM \& Rosenfeld RG 1994a The IGF axis in the prostate. Hormone and Metabolic Research 26 81-84.

Cohen P, Peehl DM, Baker B, Liu F, Hintz RL \& Rosenfeld RG 1994b Insulin-like growth factor axis abnormalities in prostatic stromal cells from patients with benign prostatic hyperplasia. Journal of Clinical Endocrinology and Metabolism 79 1410-1415. 
Crawford ED 1990 Combined androgen blockade. In Proceedings of the 2nd International Symposium on Recent Advances in Urologic Cancer Diagnosis and Treatment. New York: John Wiley \& Sons.

Crawford ED, Eisenberger MA, McLeod DG, Spaulding JT, Benson R, Dorr FA, Blumenstein BA, Davis MA \& Goodman PJ 1989 A controlled trial of leuprolide with and without flutamide in prostatic carcinoma. [Published erratum appears in N Engl J Med 1989321 1420] New England Journal of Medicine 321 419-424.

Cunha GR 1994 Role of mesenchymal-epithelial interactions in normal and abnormal development of the mammary gland and prostate. Cancer 74 1030-1044.

Cunha GR, Donjacour AA, Cooke PS, Mee S, Bigsby RM, Higgins SJ \& Sugimura Y 1987 The endocrinology and developmental biology of the prostate. Endocrine Reviews $\mathbf{8}$ 338-362.

Datta SR, Dudek H, Tao X, Masters S, Fu H, Gotoh Y \& Greenberg ME 1997 Akt phosphorylation of BAD couples survival signals to the cell-intrinsic death machinery. Cell 91 231-41.

Denis LJ, Carnelro de Moura JL, Bono A, Sylvester R, Whelan P, Newling D \& Depauw M 1993 Goserelin acetate and flutamide versus bilateral orchiectomy: a phase III EORTC trial (30853). EORTC GU Group and EORTC Data Center. Urology 42 119-129.

DiGiovanni J, Kiguchi K, Frijhoff A, Wilker E, Bol DK, Beltran L, Moats S, Ramirez A, Jorcano J \& Conti C 2000 Deregulated expression of insulin-like growth factor 1 in prostate epithelium leads to neoplasia in transgenic mice. PNAS 97 3455-3460.

Droller MJ 1997 Medical approaches in the management of prostatic disease. British Journal of Urology 79 (Suppl 2) 42-52.

Ferguson J, Zincke H, Ellison E, Bergstralh E \& Bostwick DG 1994 Decrease of prostatic intraepithelial neoplasia following androgen deprivation therapy in patients with stage $\mathrm{T} 3$ carcinoma treated by radical prostatectomy. Urology 44 91-95.

The Finasteride Study Group 1993 Finasteride in the treatment of benign prostatic hyperplasia. Prostate 22 291-299.

Franke TF, Yang SI, Chan TO, Datta K, Kazlauskas A, Morrison DK, Kaplan DR \& Tsichlis PN 1995 The protein kinase encoded by the Akt proto-oncogene is a target of the PDGF-activated phosphatidylinositol 3-kinase. Cell 81 727-736.

Gooch JL, Van Den Berg CL \& Yee D 1999 Insulin-like growth factor (IGF)-I rescues breast cancer cells from chemotherapy-induced cell death-proliferative and anti-apoptotic effects. Breast Cancer Research and Treatment 56 1-10.

Gormley GJ 1992 Chemoprevention strategies for prostate cancer: the role of 5 alpha-reductase inhibitors. Journal of Cell Biochemistry $\mathbf{1 6 H}$ (Suppl) 113-117.

Gormley GJ, Stoner E, Bruskewitz RC, Imperato-McGinley J, Walsh PC, McConnell JD, Andriole GL, Geller J, Bracken BR, Tenover JS, Vaughen ED, Pappas F, Taylor A, Binkowitz B \& Ng J 1992 The effect of finasteride in men with benign prostatic hyperplasia. New England Journal of Medicine 327 1185-1191.

Griffiths K, Davis P, Eaton CL, Harper ME, Turkes A \& Peeling WB 1991 Endocrine Dependent Tumors. New York: Raven.

Habenicht UF, Tunn UW, Senge T, Schroder FH, Schweikert HU, Bartsch G \& el Etreby MF 1993 Management of benign prostatic hyperplasia with particular emphasis on aromatase inhibitors. Journal of Steroid Biochemical and Molecular Biology 44 557-563.

Huynh H, Tetenes E, Wallace L \& Pollak M 1993 In vivo inhibition of insulin-like growth factor-I gene expression by tamoxifen. Cancer Research 53 1727-1730.

Huynh H, Larsson C, Narod S \& Pollak M 1995 Tumour suppressor activity of the gene encoding mammary-derived growth inhibitor. Cancer Research 55 2225-2231.

Huynh H, Yang X \& Pollak M 1996 Estradiol and antiestrogens regulate a growth inhibitory insulin-like growth factor binding protein 3 autocrine loop in human breast cancer cells. Journal of Biological Chemistry 271 1016-1021.
Huynh H, Seyam RM \& Brock GB 1998a Reduction of ventral prostate weight by finasteride is associated with suppression of insulin-like growth factor I (IGF-I), IGF-I receptor, and an increase in IGF binding protein 3. Cancer Research 58 215-218.

Huynh H, Pollak M \& Zhang J-C 1998b Regulation of insulin-like growth factor (IGF) II and IGF binding protein 3 autocrine loop in human PC-3 prostate cancer cells by vitamin D metabolite, $1,25(\mathrm{OH}) 2 \mathrm{D} 3$ and its analog EB1089. International Journal of Oncology 13 137-143.

Janknegt RA, Abbou CC, Bartoletti R, Bernstein-Hahn L, Bracken B, Brisset JM, Da Silva FC, Chisholm G, Crawford ED \& Debruyne FM 1993 Orchiectomy and nilutamide or placebo as treatment of metastatic prostatic cancer in a multinational double-blind randomized trial. Journal of Urology 149 77-82.

Jones JI \& Clemmons DR 1995 Insulin-like growth factors and their binding proteins: biological actions. Endocrine Reviews 16 3-34.

Jung-Testas I, Groyer MT, Bruner-Lorand J, Hechter O, Baulieu EE \& Robel P 1981 Androgen and estrogen receptors in rat ventral prostate epithelium and stroma. Endocrinology 109 1287-1289.

Kelloff GJ, Boone CW, Malone WF, Steele VE \& Doody LA 1992 Introductory remarks: development of chemopreventative agents for prostate cancer. Journal of Cell Biochemistry 16H (Suppl) 1-8.

Kulik G, Klippel A \& Weber MJ 1997 Antiapoptotic signalling by the insulin-like growth factor I receptor, phosphatidylinositol 3-kinase, and Akt. Molecular and Cellular Biology 17 1595-1606.

Labrie F, Dupont A, Belanger A, Lacoursiere Y, Raynaud JP, Husson JM, Gareau J, Fazekas AT, Sandow J \& Monfette G 1983 New approach in the treatment of prostate cancer: complete instead of partial withdrawal of androgens. Prostate 4 579-594.

Lamb JC, Levy MA, Johnson RK \& Isaacs JT 1992 Response of rat and human prostatic cancers to the novel 5 alpha-reductase inhibitor, SK\&F 105657. Prostate 21 15-34.

Leal SM, Liu Q, Huang SS \& Huang JS 1997 The type V transforming growth factor beta receptor is the putative insulin-like growth factor-binding protein 3 receptor. Journal of Biological Chemistry 272 20572-20576.

Lunglmayr G 1990 A multicenter trial comparing the luteinizing hormone releasing hormone analog Zoladex, with Zoladex plus flutamide in the treatment of advanced prostate cancer. The International Prostate Cancer Study Group. European Urology 18 (Suppl 3) 28-29.

Murphy LJ, Bell GI, Duckworth ML \& Friesen HG 1987 Identification, characterization, and regulation of a rat complementary deoxyribonucleic acid which encodes insulin-like growth factor-I. Endocrinology 121 684-691.

Murphy WM, Soloway MS \& Barrows GH 1991 Pathologic changes associated with androgen deprivation therapy for prostate cancer. Cancer 68 821-828.

Nickerson T \& Huynh H 1999 Vitamin D analogue EB1089-induced prostate regression is associated with increased gene expression of insulin-like growth factor binding proteins. Journal of Endocrinology $160223-229$.

Nickerson T, Pollak M \& Huynh H 1998 Castration-induced apoptosis in the rat ventral prostate is associated with increased expression of genes encoding insulin-like growth factor binding proteins 2, 3, 4 and 5. Endocrinology 139 807-810.

Oesterling JE 1995 Benign prostatic hyperplasia. Medical and minimally invasive treatment options. New England Journal of Medicine 332 99-109.

Oh Y, Muller HL, Lamson G \& Rosenfeld RG 1993 Insulin-like growth factor (IGF)-independent action of IGF-binding protein-3 in Hs578T human breast cancer cells. Journal of Biological Chemistry 268 14964-14971.

Oh YM, Nagalla SR, Yamanaka Y, Kim HS, Wilson E \& Rosenfeld RG 1996 Synthesis and characterization of insulin-like growth factor binding protein (IGFBP)-7 - recombinant human MAC25 protein specifically binds IGF-I and II. Journal of Biological Chemistry $27130322-30325$. 
Peehl DM, Cohen P \& Rosenfeld RG 1996 Role of insulin-like growth factors in prostate biology. Journal of Andrology 17 2-4.

Prins GS \& Birch L 1995 The developmental pattern of androgen receptor expression in rat prostate lobes is altered after neonatal exposure to estrogen. Endocrinology 136 1303-1314.

Prins GS, Marmer M, Woodham C, Chang W, Kuiper G, Gustafsson JA \& Birch L 1998 Estrogen receptor-beta messenger ribonucleic acid ontogeny in the prostate of normal and neonatally estrogenized rats. Endocrinology 139 874-883.

Rajah R, Valentinis B \& Cohen P 1997 Insulin-like growth factor binding protein-3 induces apoptosis and mediates the effects of transforming growth factor- $\beta 1$ on programmed cell death through a p53- and IGF-independent mechanism. Journal of Biological Chemistry 272 12181-12188.

Rhodes L, Ding VD, Kemp RK, Khan MS, Nakhla AM, Pikounis B, Rosner W, Saunders HM \& Feeney WP 2000 Estradiol causes a dose-dependent stimulation of prostate growth in castrated beagle dogs. Prostate 44 8-18.

Rittmaster RS 1994 Drug therapy - finasteride. New England Journal of Medicine 330 120-125.

Shimasaki S \& Ling N 1991 Identification and molecular characterization of insulin-like growth factor binding proteins (IGFBP-1,-2,-3,-4,-5 and -6). Progress in Growth Factor Research 3 243-266.

Smith GL, Doherty AP, Mitchell H, Hanham IW, Christmas TJ \& Epstein RJ 1999 Inverse relation between prostate-specific antigen and insulin-like growth factor-binding protein 3 in bone metastases and serum of patients with prostate cancer. Lancet 354 2053-2054.

Stoner E 1994 Three-year safety and efficacy data on the use of finasteride in the treatment of benign prostatic hyperplasia. Urology $43284-294$.

Thrasher JB, Tennant MK, Twomey PA, Hansberry KL, Wettlaufer JN \& Plymate SR 1996 Immunohistochemical localization of insulin-like growth factor binding proteins 2 and 3 in prostate tissue: clinical correlations. Journal of Urology 155 999-1003.

Torring N, Vinter-Jensen L, Pedersen SB, Sorensen FB, Flyvbjerg A \& Nexo E 1997 Systemic administration of insulin-like growth factor I (IGF-I) causes growth of the rat prostate. Journal of Urology $158222-227$.

Tsukamoto S, Akaza H, Imada S, Koiso K, Shirai T, Ideyama Y \& Kudo M 1995 Chemoprevention of rat prostate carcinogenesis by use of finasteride or casodex. Journal of the National Cancer Institute 87 842-843.

Wakeling AE, Dukes M \& Bowler J 1991 A potent specific pure antiestrogen with clinical potential. Cancer Research 51 3867-3873.

Wang LG, Liu XM, Kreis W \& Budman DR 1997 Down-regulation of prostate-specific antigen expression by finasteride through inhibition of complex formation between androgen receptor and steroid receptor-binding consensus in the promoter of the PSA gene in LNCaP cells. Cancer Research 57 714-719.

White MF \& Yenush L 1998 The IRS-signaling system: a network of docking proteins that mediate insulin and cytokine action. Current Topics in Microbiology and Immunology 228 179-208.

Wolk A, Mantzoros CS, Andersson SO, Bergstrom R, Signorello LB, Lagiou P, Adami HO \& Trichopoulos D 1998 Insulin-like growth factor 1 and prostate cancer risk: a population-based, case-control study. Journal of the National Cancer Institute 90 911-915.

Yenush L \& White MF 1997 The IRS-signalling system during insulin and cytokine action. Bioessays 19 491-500.

Zha J, Harada H, Yang E, Jockel J \& Korsmeyer SJ 1996 Serine phosphorylation of death agonist $\mathrm{BAD}$ in response to survival factor results in binding to $14-3-3$ not Bcl- $x_{\mathrm{L}}$. Cell 87 619-628.

\section{Received 12 April 2001}

Accepted 26 June 2001 